\title{
Четврти службени језик у Суботици
}

\author{
Мартин Хенцелман \\ (Грајфсвалд, Немачка)
}

Буњевци су једна од 21 признатих мањина у Србији, а само пре неколико година тешко да би ико помислио да је могуће да њихов језик у Србији постане четврти службени језик у Суботици у мају 2021. године. У питању је буневачки језик који се у различитим облицима говори у војвођанској Бачкој.

У Суботици су до недавно српски, мађарски и хрватски били службени језици. Будући да се ради о језицима који су државни и национални језици у одговарајућим земљама, њихова употреба у јавном простору представља искључиво политичку дефиницију статуса, а није првенствено језички проблем. Фокус није на питању да ли или како се језици могу користити, јер за то постоје одавно утврђене и недвосмислене норме. Уместо тога, законодавство Аутономне Покрајине Војводине и Републике Србије дефинише јавну употребу језика на јавним местима. Законом је регулисано да у општини са $15 \%$ или више припадника етничке или националне мањине, њихов језик се може аутоматски користити као служठени језик на таквом месту ${ }^{1}$.

Дакле, постоје два централна критеријума који морају бити испуњени да би се језик увео у јавни простор, и то језички и политички (при чему ситуација мађарског и хрватског јасно показује да су политичке стварности у првом плану). Размотримо укратко оба аспекта и пренесимо их на ситуацију Буњеваца. Што се тиче језичког статуса, мора се посматрати у врло посебној позадини: с једне стране је у питању колико су развијане могућности употребе језика

1 По члану 8 раније је било тако регулисано да ако овај број није био достигнут у општини, а премашивао је $25 \%$ на појединим локалитетима, онда се језик мањине такође тамо могао користити. (DUBOIS, Ch.: Construction nationale et revendications linguistiques en contexte minoritaire: le cas des Bunjevci de Bačka (Serbie). Linguistique. Grenoble 2016, стр. 193). Данас то већ не важи јер је члан број 8 избрисан (Zakon o službenoj upotrebi jezika i pisama, Sl. glasnik RS, broj 45/91, 53/93, 67/93, 48/94, 101/2005 - dr. zakon, 30/2010, 47/2018 i 48/2018 - ispr.). <mduls.gov.rs/ wp-content/uploads/ZAKON-O-SLUZBENOJ-UPOTREBI-JEZIKA-I-PISAMA040718.pdf>. [online]. [cit. 31. 10. 2021]. 
и степен нормативности, а с друге стране чињеница да буњевачки припада плурицентричном штокавском језичком подручју.

Што се стандардизације тиче, на њој се интензивно ради већ неколико година и до сада су објављени уџбеници за ђаке - читанке, школска граматика и приручник за наставнике, као и друго, допуњено издање Речника бачких Буњеваца. Часописи и листови попут „Буњевачких новина”, „Тандрчка”, „Ричи Буњевачке матице”, „Буњевачког пригледа” и др. редовно се издају и постоје бројни књижевни текстови, тако да се може видети да засигурно постоји основа за употребу буњевачког језика. Оно што је до сада било мање у првом плану су публикације које су посвећене свеобухватној лингвистичкој дискусији и које превазилазе ниво школе. Међутим, воља да се то исправи је јасно уочљива, јер су већ чињени покушаји да се језик угради у универзитетски контекст и понуди као предмет, али то још увек није реализовано.

Велика предност на коју може да укаже процес стандардизације је несумњиво чињеница да језик Буњеваца припада плурицентричном штокавском језичком подручју, које игра улогу на свим језичким нивоима. Посебност је у томе што је буњевачки заснован на икавици, иако данас екавица често доминира у говорном контексту или се јављају мешовити облици. Међутим, нема потребе за успостављањем сопственог правописног система, тако да се елиминише проблем са којим се суочавају бројне друге језичке мањине у Европи које су такође заинтересоване за стандардизацију својих идиома (као што је случај, на пример, са горњошлеским у Пољској). Уместо тога, може се доследно служити латиницом, која се у идентичном облику користи у Хрватској или у Србији. Ово је такође повезано са чињеницом да у оквиру фонетике и фонологије, морфологије и синтаксе постоји опсежна аналогија са штокавским језичким простором. Оно што примећујемо су одрећене преференције које су наглашене за језик Буњеваца, као што је препоручена употреба крнеі инфинитива уместо gа-конструкције $e^{2}$ или одређена необична лексика. Кључна ствар је да у службеним документима не постоји препознатљива препрека за употребу буњевачког језика, јер су правопис, граматичка структура и лексика која ће се користити доступни или се могу преузети из српског или хрватског језика без потребе за семантичким појашњењем за носиоца језика (осим правних терминолошких специфичности, којима се ионако баве само правници). Другим речима, бар теоретски, нема разлога да се варијанта штокавског подручја не користи у писању, као ни већ стандардизоване варијанте које функционишу као државни језици.

2 POPOV, A. - KUJUNDŽIĆ OSTOJIĆ, S.: Gramatički i pravopisni priručnik bunjevačkog jezika. Budisava 2019, стр. 36 . 
Оно што остаје је разматрање политичког контекста. Основа за то регулисана је горе поменутом законском структуром, али је потребна одговарајућа одлука о питању да ли и под којим условима одређени језик добија службени статус. Тако је дошло до „јавне расправе о увођењу буњевачког као службеног језика”, у којој се у градској кући водила суштинска расправа о предностима и недостацима увођења језика Буњеваца у службену употребу. Било је могуће контактирати секретаријат градске скупштине у Суботици, и представити мишљења или препоруке које би могле бити узете у обзир при одлучивању. Укупно је било 88 поднесака ${ }^{3}$. Током дискусије морало се размотрити да ли треба изменити Статут града и додати буњевачки као службени језик.

Међутим, такође се мора узети у обзир да је целокупна расправа о статусу Буњеваца одавно и пре свега политикум. Иако српски и мађарски политичари на терену немају никаквих посебних проблема са Буњевцима и самоопредељењем својих говорника, целокупна констелација око независног буњевачког језика или идентитета већ је увреда за локалне хрватске политичаре и оне Буњевце који себе виде као Хрвате. Сходно томе, хрватска страна у расправи жестоко се опирала напредовању и одбила је да буњевачки призна као језик.

Неколико дана касније, „Политика” је известила да је градска скупштина одобрила ствар без гласова против и усвојила измену Статута града Суботице, тако одлучила да Буњевцима додели право које имају и друге заједнице. Међутим, ово гласање бојкотовали су хрватски посланици (у моменту има само два хрватска одборника). Ипак, за Буњевце је резултат огроман успех ${ }^{4}$, јер је то одлука која ће несумњиво повећати престиж и интересовање за групу и њен језик. Ускоро ће се појавити нове квантитативне и квалитативне опције у развоју писаног језика, показаће нам се да мале заједнице могу много постићи ако ефикасно користе могућности које им пружа закон. Остаје да се види који ће се конкретни кораци сада предузети да би се буњевачки језик користио у јавном простору на ефикасан начин и да ли ће се на основу тога постићи даљи напредак, на пример да се захтева увођење службеног буњевачког језика у другим местима. Без сумње, врло значајан догађај је сензационална одлука донета у мају 2021. године у граду Суботици.

3 Javna rasprava o uvođenju bunjevačkog kao službenog jezika. Politika, sreda, 28.04.2021. <https://www. politika.rs/scc/clanak/477876/Javna-rasprava-o-uvodenju-bunjevackog-kao-sluzbenog-jezika>. [online]. [cit. 31. 10. 2021].

4 Subotica ima četri jezika u službenoj upotribi. Bunjevci, četvrtak, 06.05.2021. <http://bunjevci.net/ visti/22-visti/1805-subotica-ima-etri-jezika-u-sluzbenoj-upotribi>. [online]. [cit. 31. 10. 2021]. 


\section{Литература:}

DUBOIS, Ch.: Construction nationale et revendications linguistiques en contexte minoritaire: le cas des Bunjevci de Bačka (Serbie). Linguistique. Grenoble 2016.

Javna rasprava o uvođenju bunjevačkog kao službenog jezika. Politika, sreda, 28.04.2021. <https://www.politika.rs/scc/clanak/477876/Javna-rasprava-o-uvodenjubunjevackog-kao-sluzbenog-jezika>. [online]. [cit. 31. 10. 2021].

POPOV, A. - KUJUNDŽIĆ OSTOJIĆ, S.: Gramatički i pravopisni priručnik bunjevačkog jezika. Budisava 2019.

Subotica ima četri jezika u službenoj upotribi. Bunjevci, četvrtak, 06.05.2021. <http:// bunjevci.net/visti/22-visti/1805-subotica-ima-etri-jezika-u-sluzbenoj-upotribi> . [online]. [cit. 31. 10. 2021].

Zakon o službenoj upotrebi jezika i pisama, Sl. glasnik RS, broj 45/91, 53/93, 67/93, 48/94, 101/2005 - dr. zakon, 30/2010, 47/2018 i 48/2018 - ispr.). <mduls.gov.rs/wp-content/ uploads/ZAKON-O-SLUZBENOJ-UPOTREBI-JEZIKA-I-PISAMA040718.pdf>. [online]. [cit. 31. 10. 2021].

\section{About the author \\ Martin Henzelmann \\ University of Greifswald, Faculty of Arts and Humanities, Department of Slavonic Studies, Greifswald, Germany martin.henzelmann@uni-greifswald.de}

